$$
\begin{aligned}
& \text { بررسى اثر مهار زيستى قارج Macrophomina phaseolina توسط باكترى سودوموناس } \\
& \text { فلورسنت بر روى لوبيا و ارزيابى ميزان فنل كل ريشه }
\end{aligned}
$$

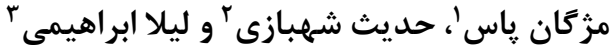

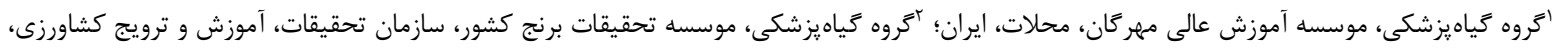

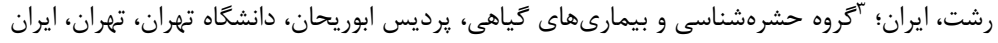

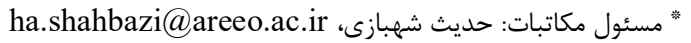

جكيده. بيمارى يوسيدگى ذغالى ناشى از قارج Macrophomina phaseolina يكى از مهمترين بيمارىهاى خاكزاد گياهان مختلف از جمله لوبيا است كه همه ساله

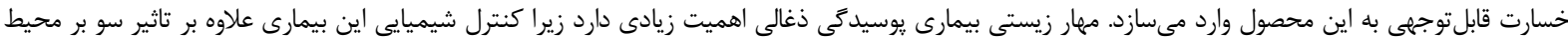

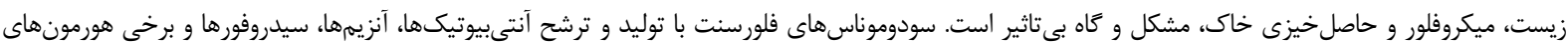

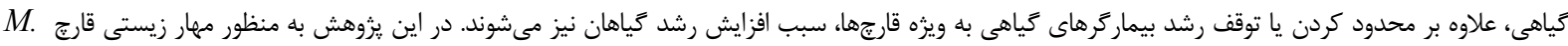

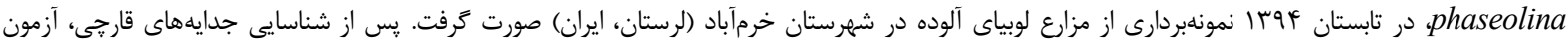

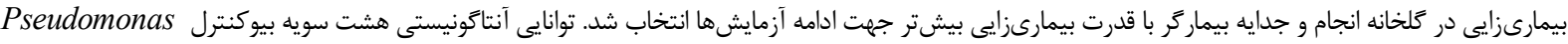
S. phaseolina در شرايط آزمايشكاهى مورد بررسى قرار كرفت. fluorescens

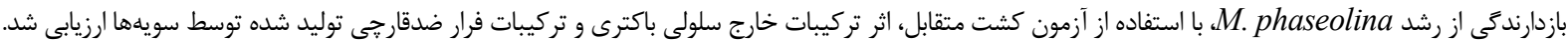

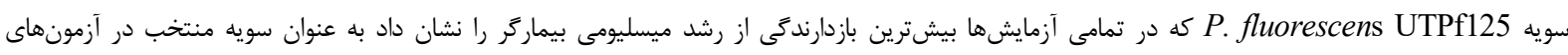

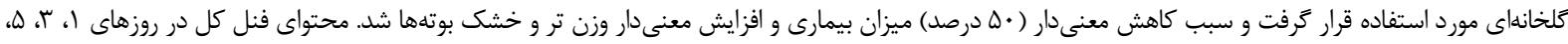

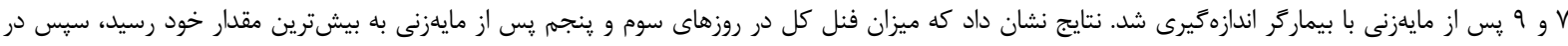
روزهاى هفتم و نهم كاهش يافت.

وازمهاى كليدى. آنتاكونيست، آنتىبيوتيك، بيمارىزايى، يوسيدگى ذغالى، تركيبات فرار

\title{
The biocontrol potential of Pseudomonas fluorescens against Macrophomina phaseolina and estimating the total phenol compounds of bean roots
}

\begin{abstract}
Mozhghan Pas ${ }^{1}$, Hadis Shahbazi ${ }^{2}$ \& Leila Ebrahimi ${ }^{3}$
${ }^{1}$ Department of Plant Protection, Mehregan Institute of Higher Education, Mahalat, Iran; ${ }^{2}$ Department of Plant Protection, Rice Research Institute of Iran, Agricultural Research, Education and Extension Organization (AREEO), Rasht, Iran; ${ }^{3}$ Department of Entomology and Plant Pathology, Aburaihan Campus, University of Tehran, Tehran, Iran

${ }^{*}$ Correspondent author: Hadis Shahbazi, ha.shahbazi@areeo.ac.ir

Abstract. Charcoal rot caused by Macrophomina phaseolina is one of the most important soil borne diseases with a broad host range including bean, which annually brings a significant damage to this plant. Biological control of charcoal rot is very important because its chemical control harms the environment, microflora and soil fertility. Chemical control of charcoal rot is also difficult and sometimes ineffective. Fluorescent Pseudomonads are able to increase plant growth and inhibit the development of plant pathogens by producing and secreting antibiotics, enzymes, siderophores, and plant hormones. In this study, infected bean plants by $M$. phaseolina were collected from infected bean fields of Khorramabad (Lorestan Province, Iran) in the summer of 2015. Virulence of fungal isolates was evaluated in a greenhouse and one isolate with the highest pathogenicity was chosen for further experiments. The biocontrol potential of
\end{abstract}


eight Pseudomonas fluorescens strains, whose biocontrol abilities were proved in previous studies, was examined against $M$. phaseolina in vitro. The growth inhibition of $M$. phaseolina was examined by dual culture test and the antifungal activity of bacterial volatile and nonvolatile metabolites. P. fluorescens UTPf125, which showed the highest inhibitory effect on the mycelial growth, was selected for greenhouse tests. UTPf125 strain led to a significant reduction $(\% 50)$ of disease severity and increased fresh and dry weight significantly. Phenol compounds were evaluated 1, 3, 5, 7 and 9 days after inoculation by pathogen. The results showed that the highest value of total phenol content was obtained on the third and fifth days after inoculation, decreasing on the seventh and ninth days.

Keywords. antagonist, antibiotic, charcoal rot, pathogenicity, volatile metabolites

ميكروار گانيسههاى آنتاكونيست در كنترل بيمارىهاى قارجى و و

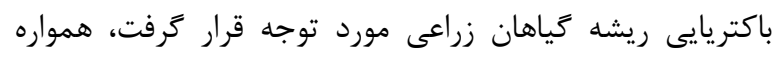

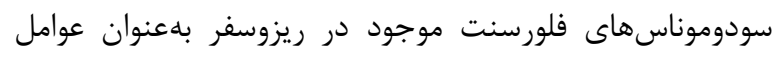

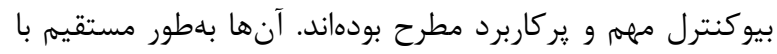

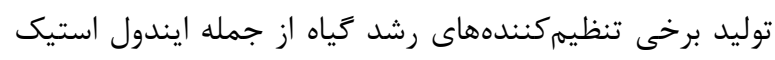

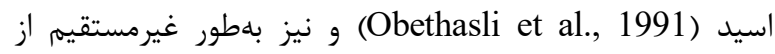
طريق مهار زيستى بيماركرها و القا مقاومت در خياهان سبب افزايش رشد آنها و كاهش خسارت عوامل بيمارىزا مىشوند

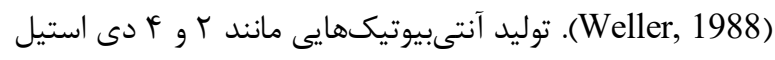

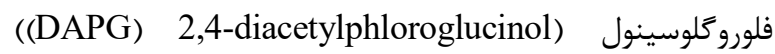
(Shanahan et al., 1992; Keel et al., 1992) ،(Brisbane et al., 1987; Mazzola et al., 1992) يائولوتئورين (Howell \& Stipanovic, 1980) و پيرولنيترين (Chancey et al., 2002)، سيدروفورهاى نوع سودوباكتين

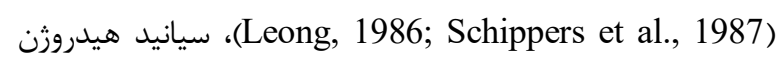
Keel \& ) و آنزيمهاى يروتئاز (Voisard et al., 1989) از مهمترين سازوكارهاى مؤثر در مهار زيستى آنى (Defago, 1997

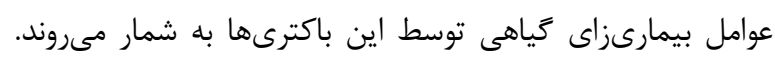

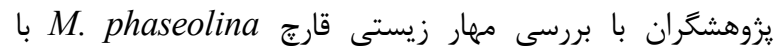

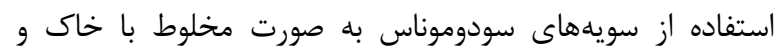

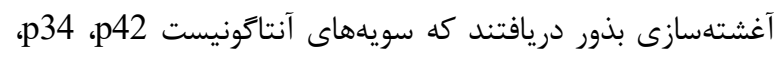

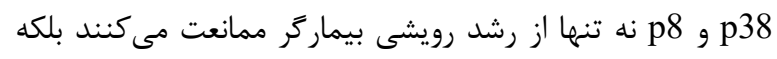

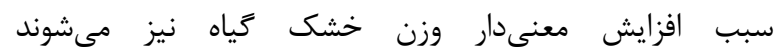
(Golpayegani et al., 2011)

ياسخ عمومى كياهان در برابر تنشهاى زيستى و غيرزيستى

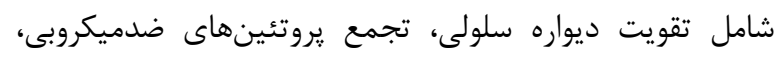

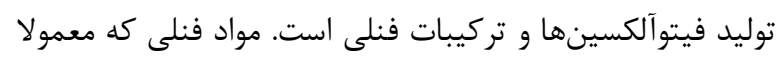

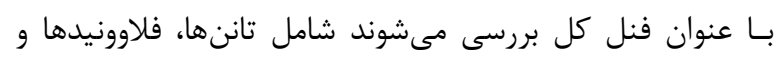

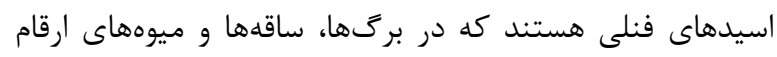

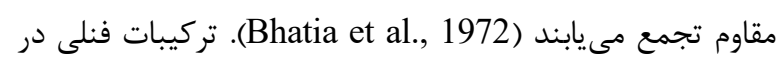
شرايط محيطى مطلوب نيز در سلولهاى تياهى توليد مى شيوند اما

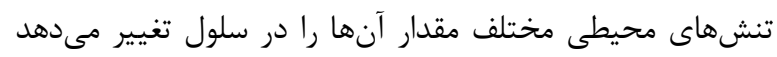

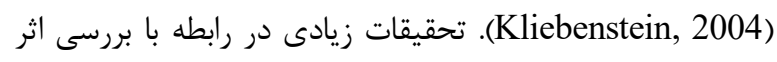

مقبدمهات يس از غلات دومين منبع غذايى به شمار مىروند كه

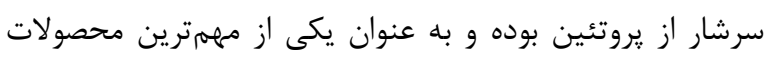

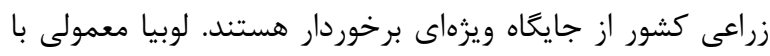

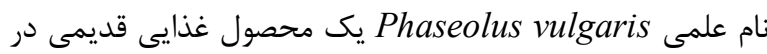

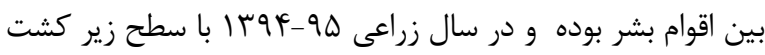

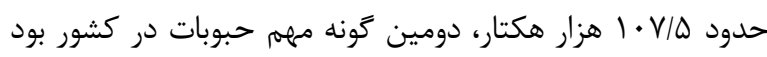

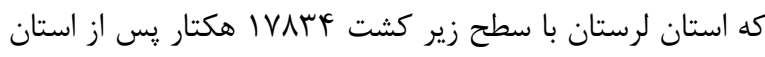

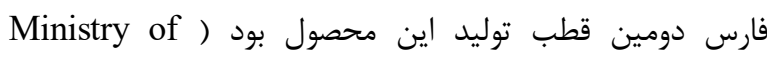
T. Agriculture Statistics, 2017

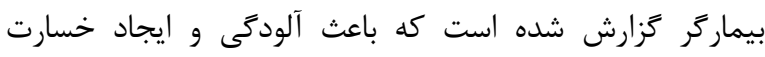

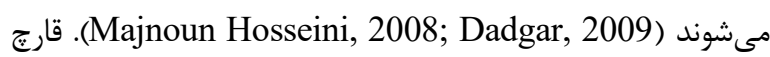
Macrophomina phaseolina (Tassi) Goid يوسيدگى ذغالى يكى از عوامل بيمارىزاى خاكزاد است كه ريشه

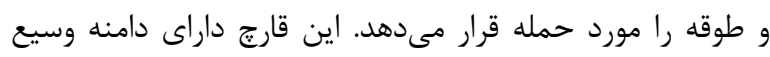

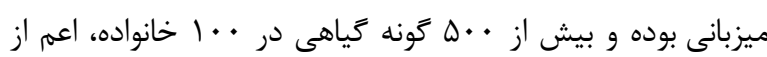

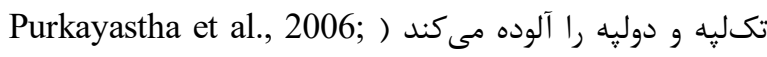

.(Dhingra \& Sinclair, 1973

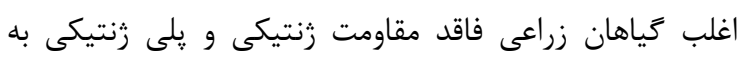

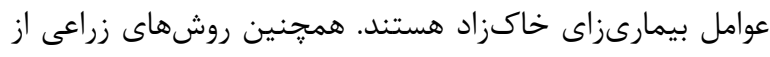

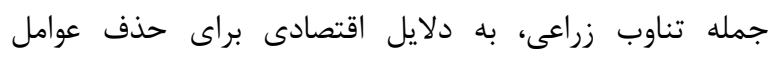

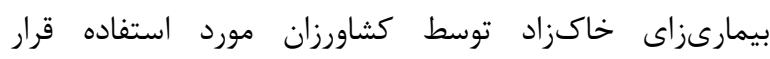

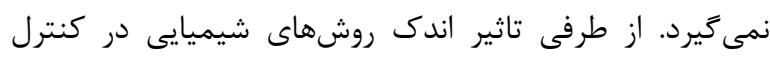

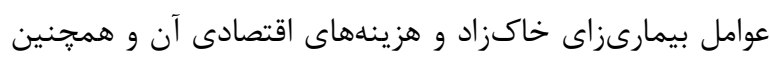

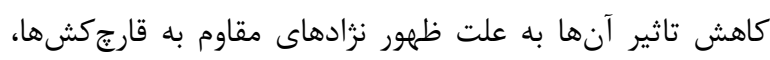

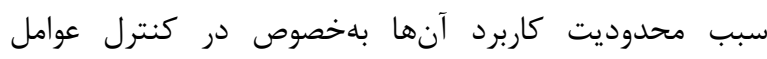

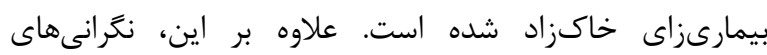

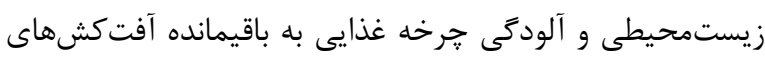

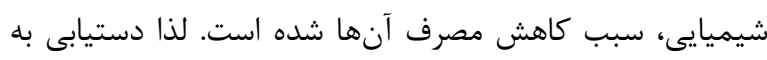

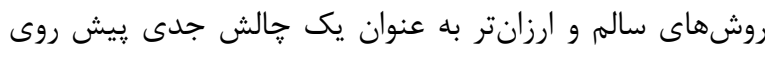

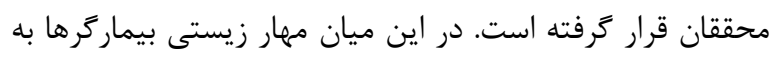

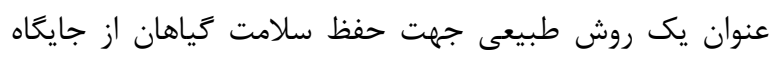

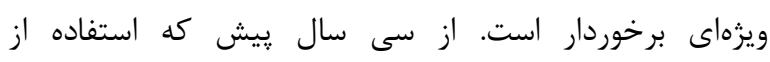


با قطر دهانه · r سانتىمتر ريخته شد. سيس زادمايه قارج بيمارگر به نسبت • ا درصد وزنى بطور يكنواخت با خاك مخلوط

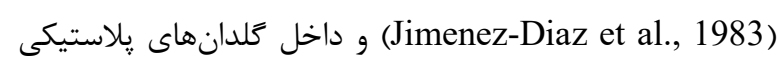

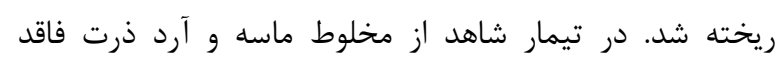
زادمايه قارج استفاده شد. به سه سانتىمتر فوقانى هر يكى از

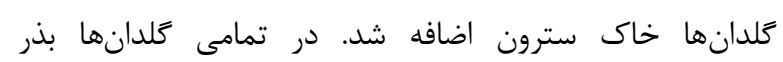
ضدعفونى شده لوبيا قرمز رقم محلى در عمق دو سانتى مترى از

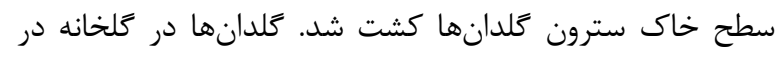
دماى هr-YV درجه سانتى شش تيمار (ينج جدايه قارجى و شاهد) در سه تكرار انجام شد.

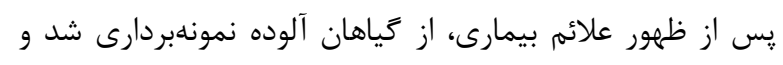

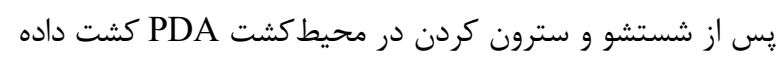

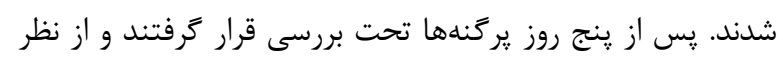

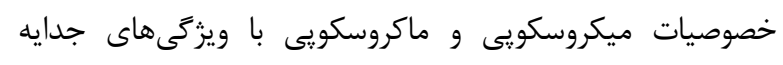
اصلى مقايسه شدند. جدايهاى كه شدت بيمارىزايى بيشترى داشت براى ادامه آزمايشها مايسه انتخاب شد.

باكترى هاى بيوكنترل

هشت سويه مختلف باكترى بseudomonas fluorescens بائت نامهاى UTPf125، UTPf110،P13، UTPf105، UTPf127، UTRf104 و UTPf120 كه در يزوهش Uهاى قبلى توانايى (Madloo, 2013; Shahbazi et al., 2016) مهارزيستى آنها به اثبات رسيده بود، از كلكسيون كنترل

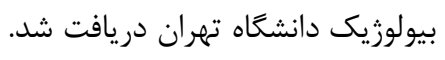

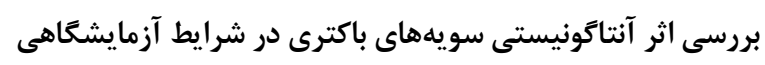
آزمون كشت جههار نقطهاى

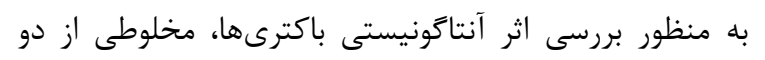

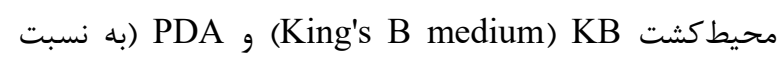
1:(1) تهيه شد. هشت سويه باكترى بهصورت جداكانه به مدت

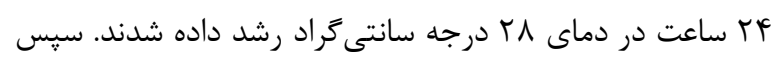

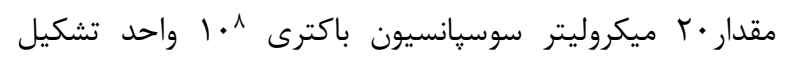

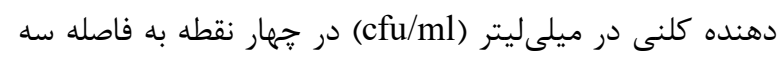

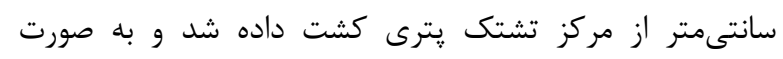

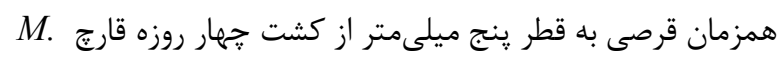
بترى دhaseolina

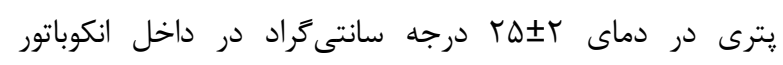
نتخهدارى شدند. آزمايش در نه تيمار (هشت سويه باكترى و شاهد)

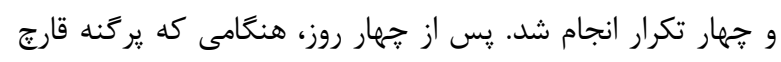

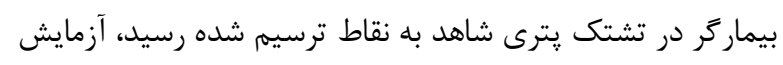

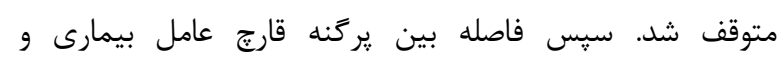

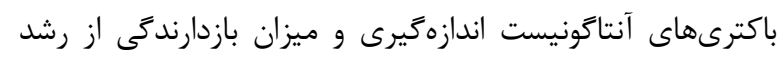

ميسليومى تعيين شد (Expert \& Digat, 1995).
تركيبات فنلى در مقاومت بـه عوامل بيمارىزا انجام شده است كه نشان مىدهد مقاومت زياه بـهـ عامل بيماريزا، وابسته بـــه حضور

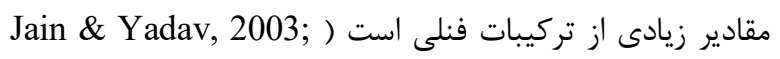
(Parashar \& Lodha, 2007; Shahbazi et al., 2010 P. در اين يزوهش، اثر بيوكنترلى سويههاى باكترى

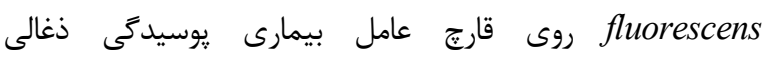
خالصسازى شده از ريشه و طوقههاى آلوده لوبيا، در شرايط آزمايشگاهى و كلخانهاى مورد ارزيابى قرار گرفت.

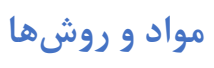
قارج عامل بيمارى

نمونهبردارى از ريشه و طوقه زياهان آلوده مزارع كشت لوبيا

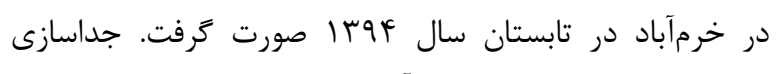
عامل بيمارى مطابق روش آزمايش شده پيشين انجام شد (Ammarlou et al., 2010; Chehri et al., 2010) خالصسازى قارج Macrophomina به صورت نوى ريسه يا تك-اسكلروت روى محيط كشت سيبزمينى -دكستروز-آكار (PDA) اساس ويزگى هاى ريختشناسى شامل سرعت رشد يرگنه، رنت إنى

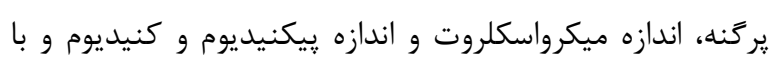
استفاده از توصيفهاى در دسترس شناسايى شدند ( Ershad \&

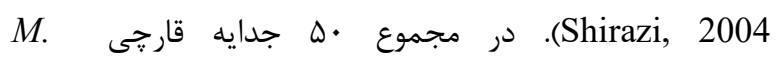
phaseolina اساس سرعت رشد يرگنه روى محيط كشت جهت انجام آزمون بيمارىزايى انتخاب شدند.

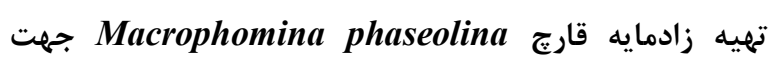
انجام آزمونهاى كلخانهاى زادمايه

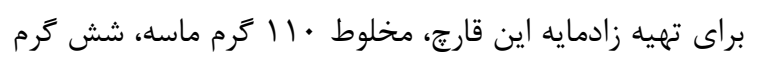

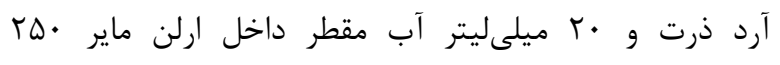

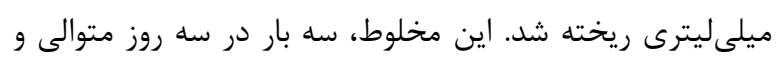

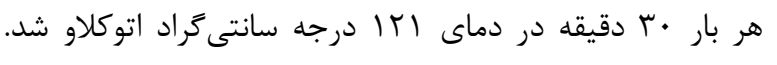

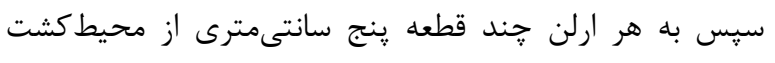
هفت روزه قارج روى محيط PDA اضافه شد. ارلنها در انكوباتور

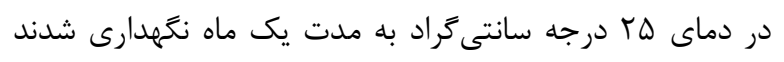
(Etebarian et al., 2007)

آزمون اثبات بيمارىزايى جدايههاى Macrophomina phaseolina مخلوطى از خاك مزرعه و شن و خاى برى به نسبت وزنى

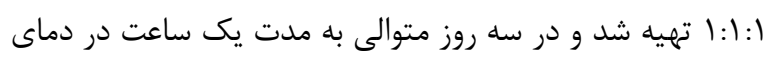

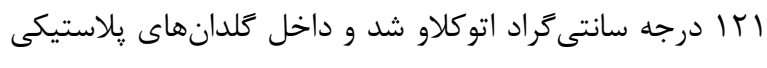




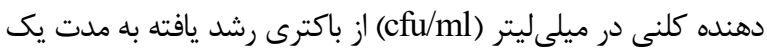

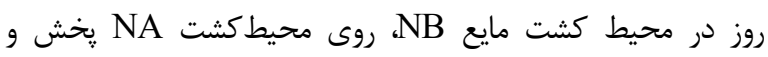
همزمان يك قرص ميسليومى از كشت جهار روزه قارج روى دريط محيطكشت PDA كشت داده شد. دو تشتك يترى حاوى كشت باكترى و قارج در مقابل هم قرار داده شدند و شكاف بين دو تشتك دان

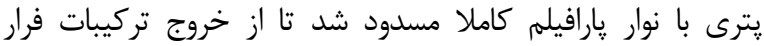
باكتريايى جلوگيرى شود. در تيمار شاهد به جاى آنائ سوسيانسيون

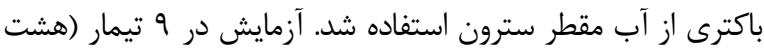
سويه باكترى و شاهد) و جهار تكرار انجام شد. تشتكها به به مدان

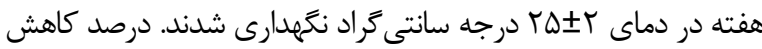

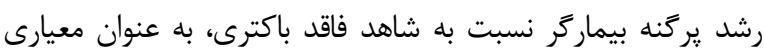
جهت ارزيابى اثر ضدميكروبى تركيبات فرار مورد استفاده قرار كرفت برتئ. بررسى اثر بيوكنترلى باكترى منتخب روى بيمارى يوسيدكى ذغالى لوبيا در شرايط كَلخانهاى

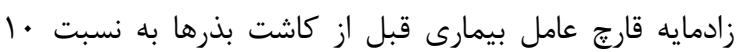

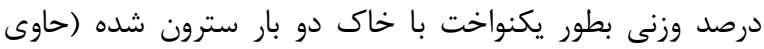

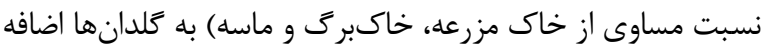

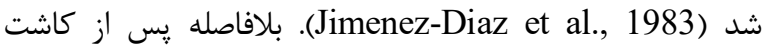

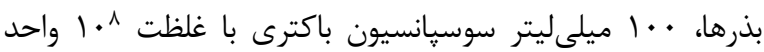

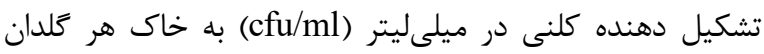

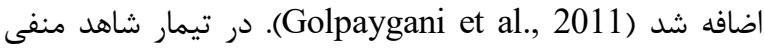

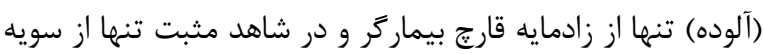
باكترى استفاده شد و در شاهد سالم از هيجكدام استفاده نشد.

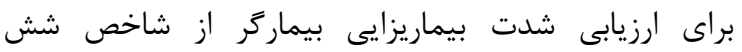

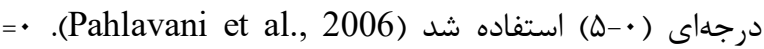

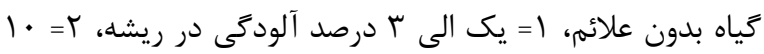

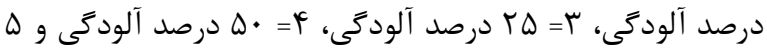
= بيش از VD درصد آلودىى. به منظور بررسى اثرات متقابل

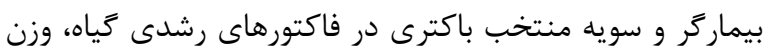

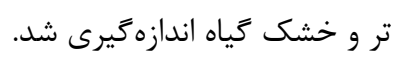

اندازهيرى محتواى فنل كل در تياهان تيمار شده با قارج بيماركر و باكترى بيوكنترل

به منظور اندازهيرى مقدار كل تركيبات فنلى موجود در عصاره

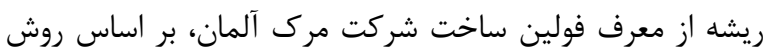

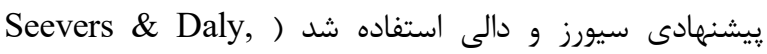
1970). براى استخراج تركيبات فنلى، به ترتيب در روزهاى ا، "َ،

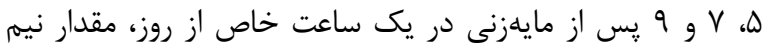

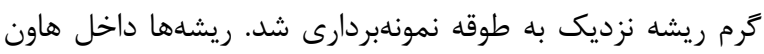

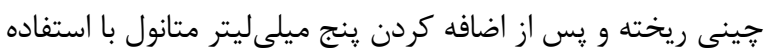

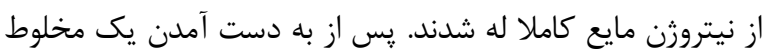

آزمون كشت متقابل

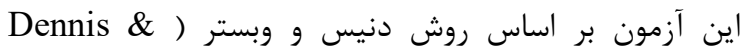
(Webster, 1971

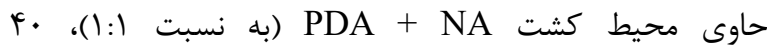

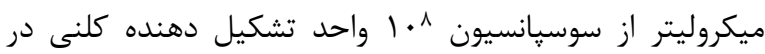

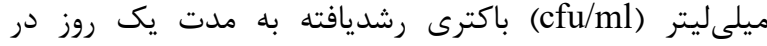

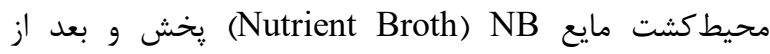
كذشت مF TF ساعت در فاصله يك سانتىمترى از لبه نيمه ديخر

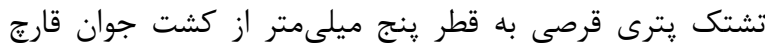

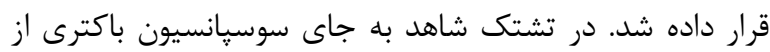

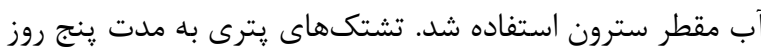

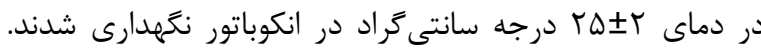

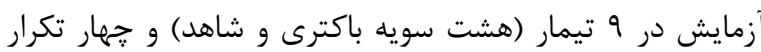

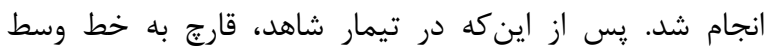

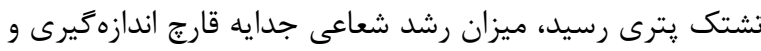
سيس مساحت يركنه قارجى محاسبه شد و در نهايت ندايت درصد كاهش رشد ميسليوم قارج به شرح زير ( Etebarian et al., 2005) محاسبه شد. $n=(a-b) / a \times 100$

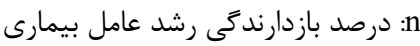

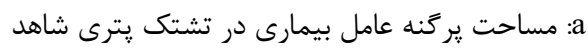

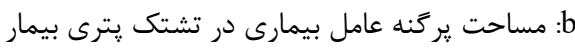

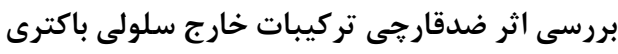

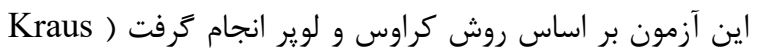

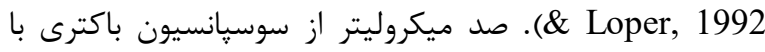
جمعيت ^• ا واحد تشكيل دهنده كلنى در ميلىليتر (cfu/ml)

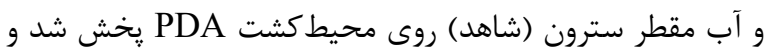

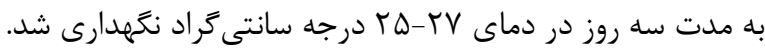

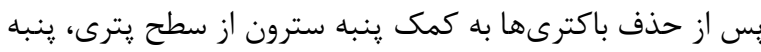

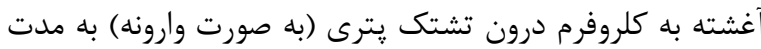

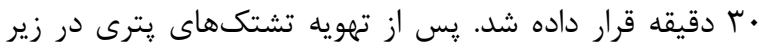

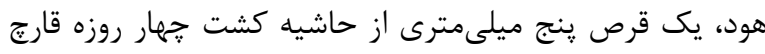
در مركز هر تشتى قرار داده شد. آزمايش در 9 تيمار (هشت

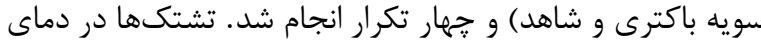

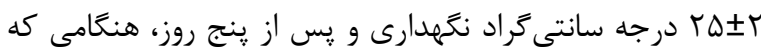

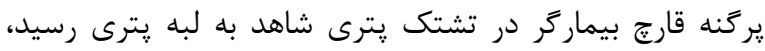

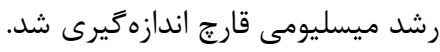
بررسى اثر ضدقارجى تركيبات فرار باكترى

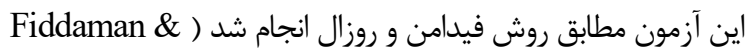

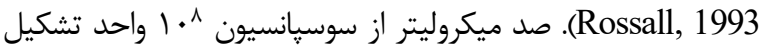


معرف فولين و كربنات كلسيم اشباع، جذب نورى آن در دستكاه

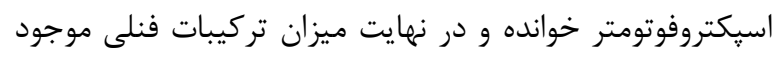
در نمونها به صورت ميلى كياه تعيين شد (1970) .al., 1977; تجزيه آمارى تمامى آزمونها در آزمايشكاه و آزمون بيمارىزايى در قالب

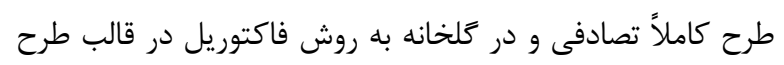

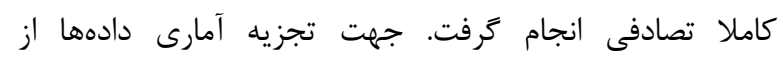
نرم|فزار SAS ver. 9.1 استفاده شد و مقايسه ميانگينها توسط

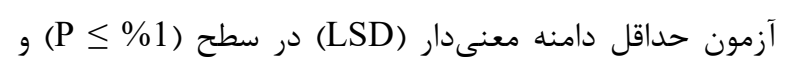

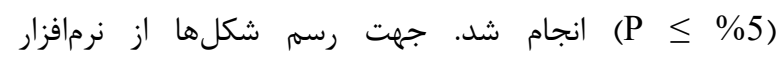
Microsoft excel, 2013

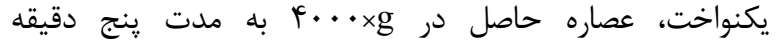

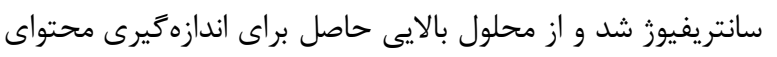

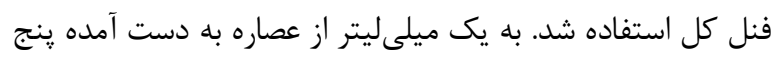

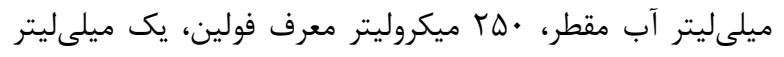

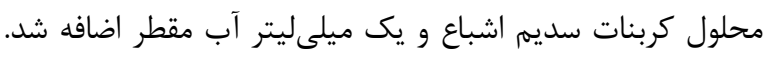

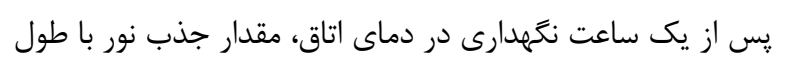

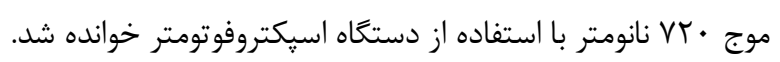
لولههاى شاهد شامل آب و معرف فولين بودند. از هر نمونه عصاره

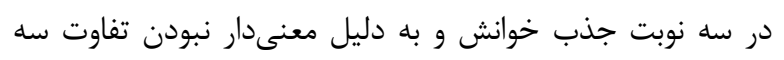

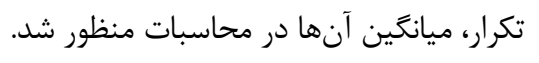

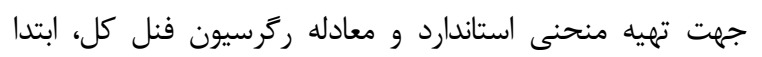

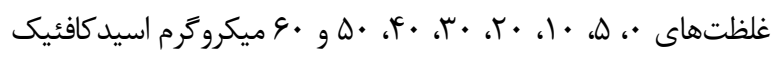

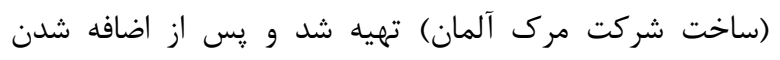

A

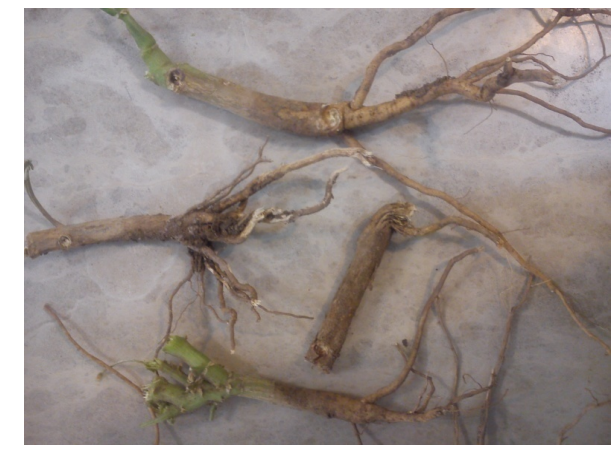

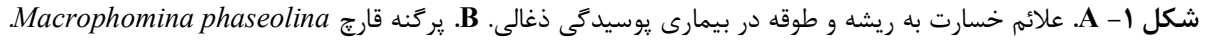

Fig. 1. A. Charcoal rot symptoms in collar and root. B. Colony of Macrophomina phaseolina.
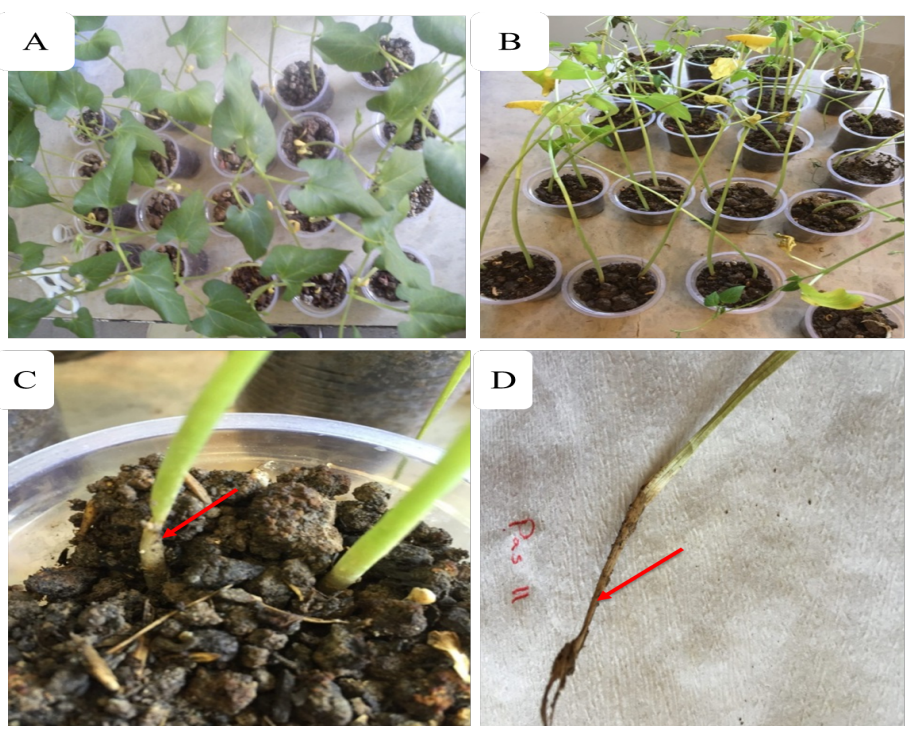

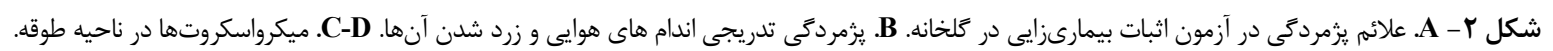
Fig. 2. A. Wilt symptoms in pathogenicity test in greenhouse. B. Gradual wilting and yellowing of plant aerial parts. CD. Microsclerotia on bean collar. 
در آزمون اثبات بيمارىزايى، يرمردگى تدريجى اندامهاى هوايى و

نتايج

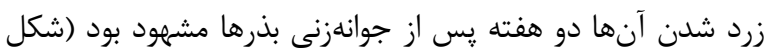
قارج عامل بيمارى

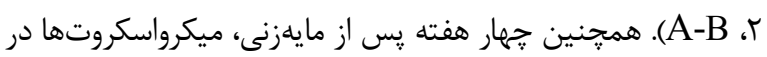

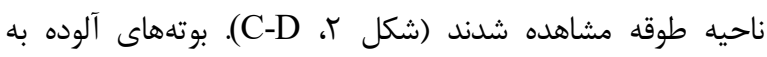

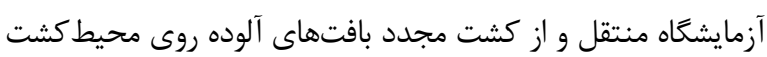

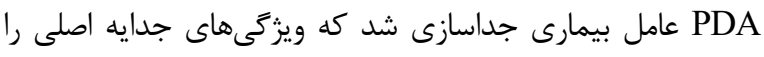

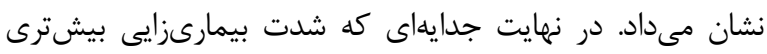

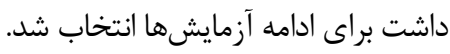

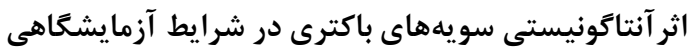

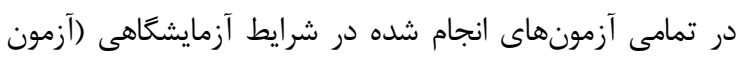
كشت جهار نقطهاى، كشت متقابل، متابوليتهاى غيرفرار و تركيبات

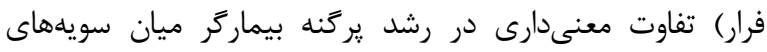

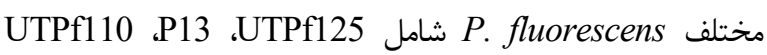

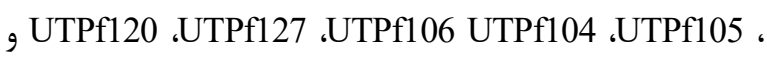
شاهد مشاهده شد. نتايج حاصل از هر جهار آزمون نشان داد كه

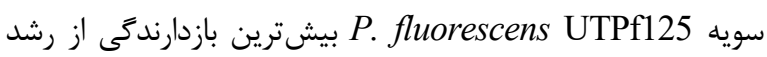

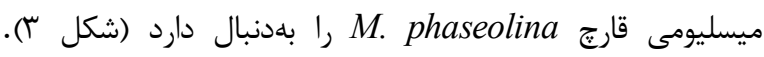
بنابر اين، اين سويه جهت انجام آزمونهاى كلخانهاى انتخاب شد.

ينجاه جدايه قارجى از ريشه و طوقه گياهان آلوده به بوتهميرى

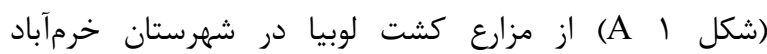
جداسازى و خالصسازى شد. ويزگى هاى ريختشناسى قارج

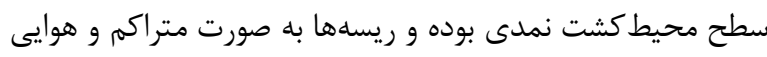

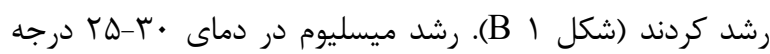

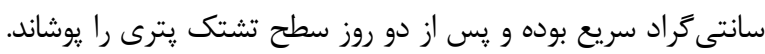

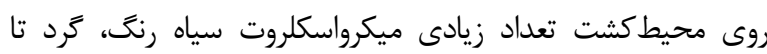

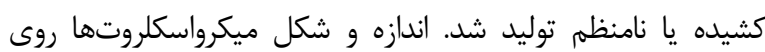
محيطهاى مختلف و در بين جدايههاى مختلف متفاوت بود.

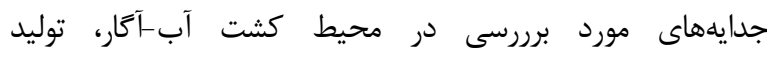

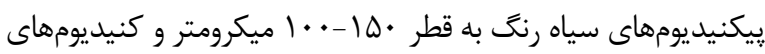

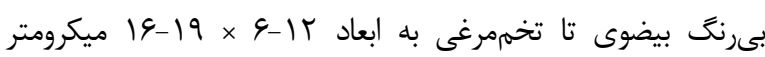

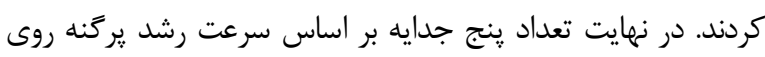

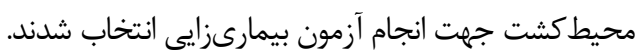

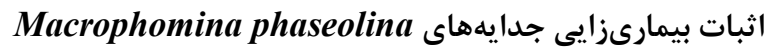
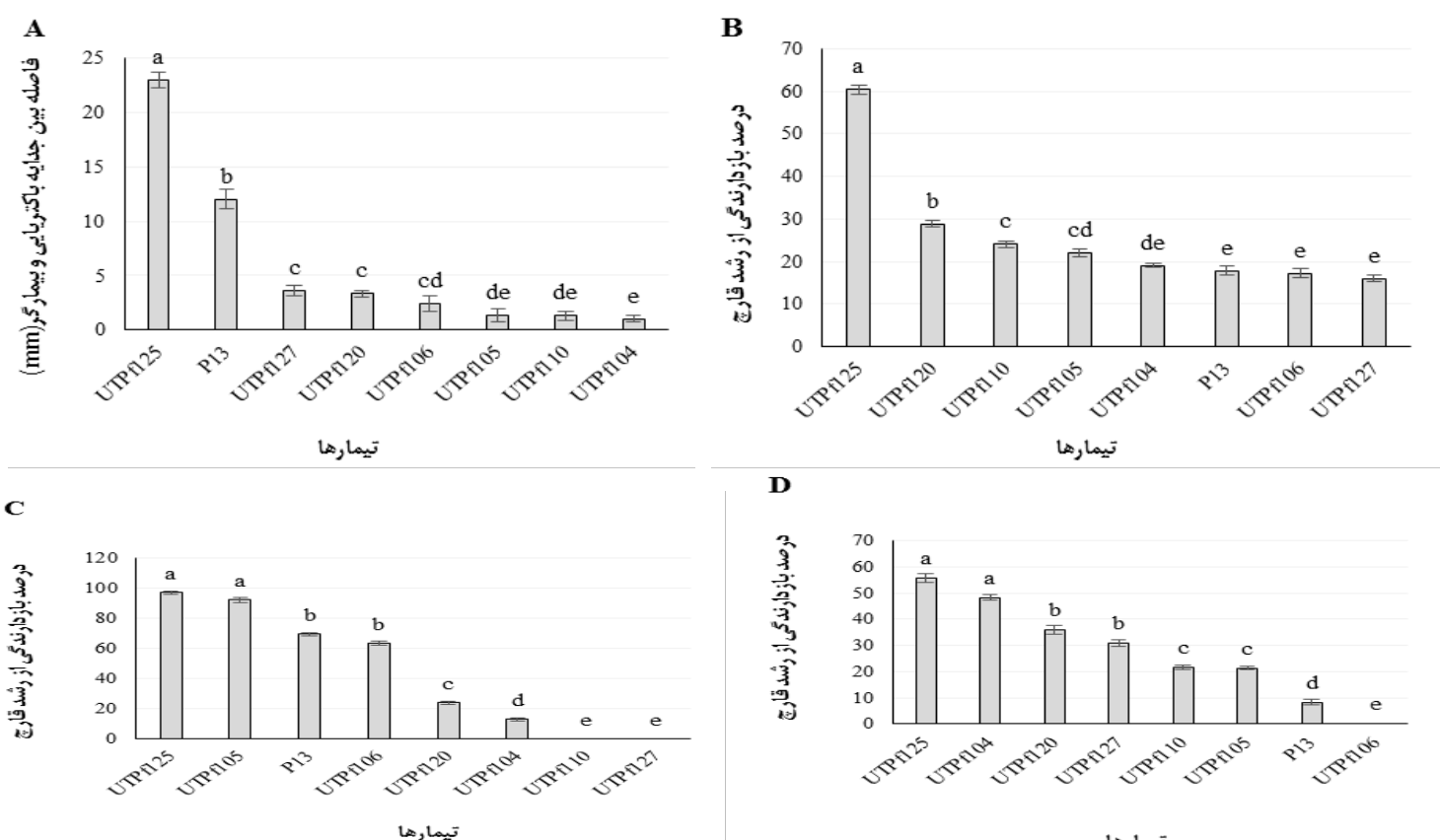

D

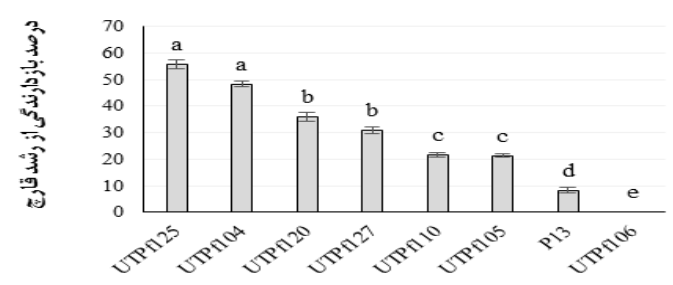

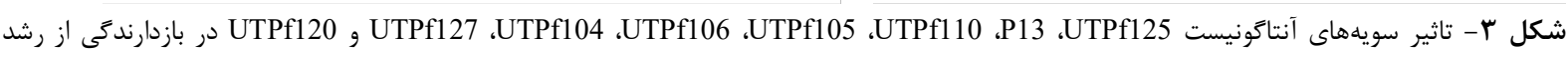

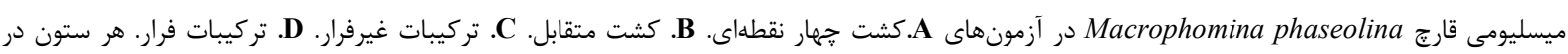

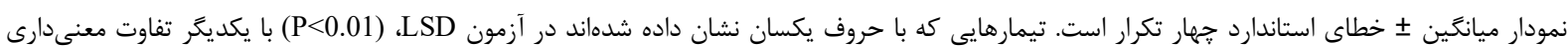
ندارند.

Fig. 3. The effects of antagonistic strains UTPf125, P13, UTPf110, UTPf105, UTPf106, UTPf104, UTPf127 and UTPf120 on Macrophomina phaseolina mycelial growth in A. Four point test. B. Dual culture. C. Nonvolatile metabolites. D. Volatile metabolites. Data are the means $\pm \mathrm{SE}$ of four replicates. Treatments with the same letters do not differ significantly $(\mathrm{P}<0.01)$ according to LSD test. 


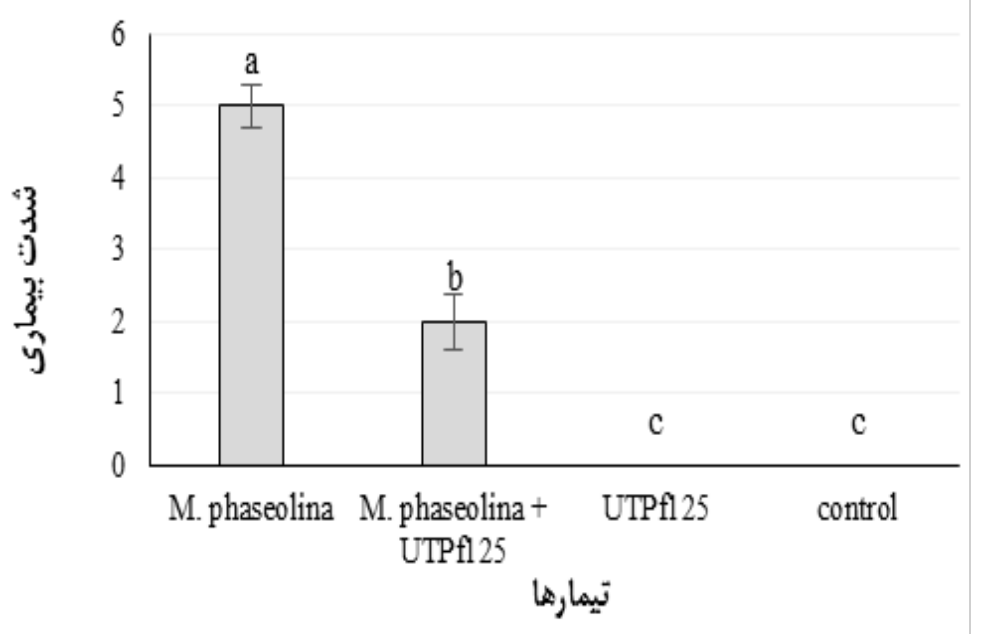

شكل F - شدت بيمارى در تيمارهاى مختلف با استفاده از شاخص شش درجهاى. هر ستون در نمودار ميانگين 土 خطاى استاندارد جهار تكرار است. تيمارهايى

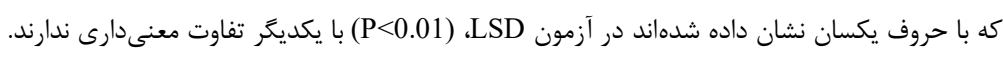
Fig. 4. The disease severity of different treatments obtained by using the six-point index. Data are the means \pm SE of four replicates. Treatments with the same letters do not differ significantly $(\mathrm{P}<0.01)$ according to LSD test.

وزن تر و خشك تياه در تيمارهاى مختلف آ.

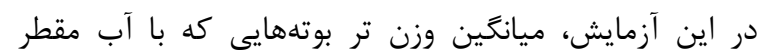

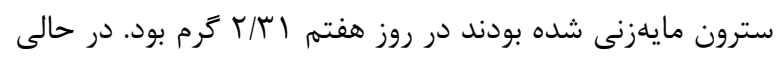

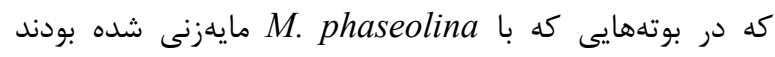

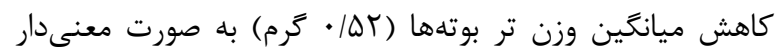
M. phaseolina مشاهده شد. در تيمارهايى كه مايهزنى آنها و P. fluorescens انجام شده بود، ميانگين وزن تر كائ خياهان l/V9

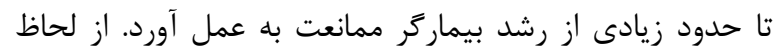
آمارى اختلاف معنى دارى ميان وزن تر تيمارهاى مايهزنى شده با

$$
\text { سوسيانسيون باكترى و شاهد وجود نداشت (شكل هاري ه). }
$$

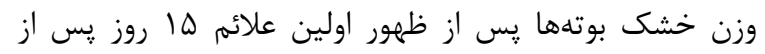

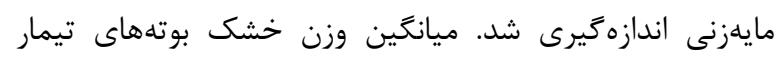
شاهد كه با آب مقطر سترون مايهزنى شده بودند 11/ • • گرم بود.

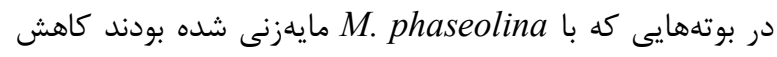
ميانگين وزن خشك بوتهها به صورت معنى دارى مشاهده شد. در

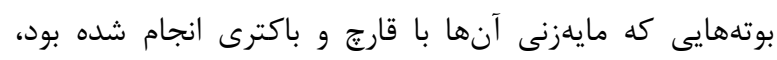

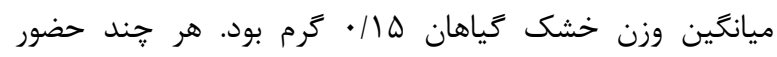
باكترى بيوكنترل سبب كاهش شدت بيمارى توسط بيمارگر شده

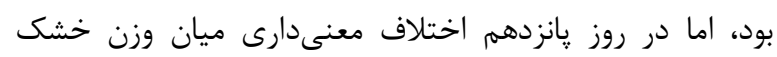
بوتههاى آلوده در حضور و غياب باكترى بيوكنترل مشاهده نشد.

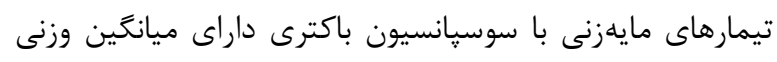

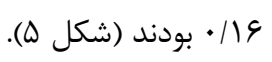

اثر بيوكنترلى باكترى منتخب روى بيمارى يوسيدكى ذغالى لوبيا در شرايط كلخحانهاى باي در آزمونهاى كلخانهاى، همان طور كه انتظار مىرفت در در كياهان

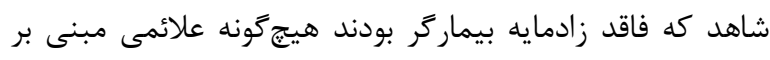

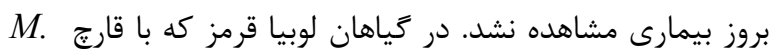
phaseolina ظاهر شد. در تمامى گياهانى كه تنها با بيمارگر تيمار شده بودند

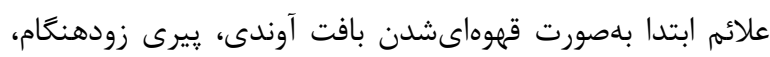

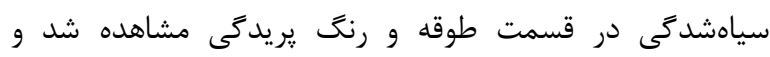

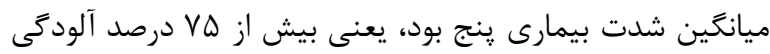

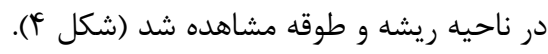

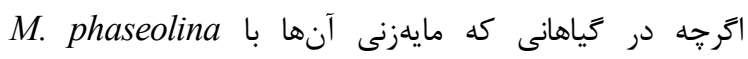
و P. fluorescens UTPf125 انجام شده بود نيز اولين علائم

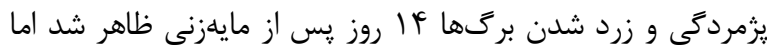

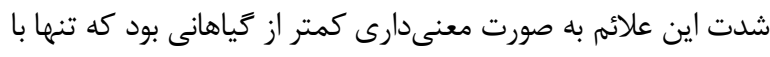
M. phaseolina

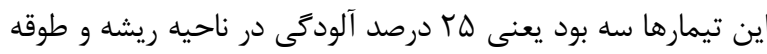

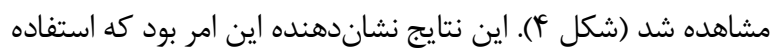

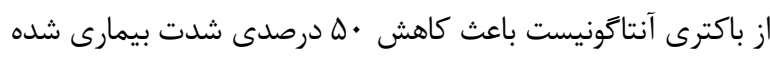
است. در تيمارهايى كه تنها با سويه باكترى مايهزنى شده بودند،

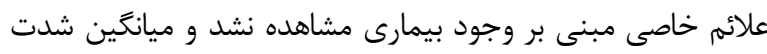

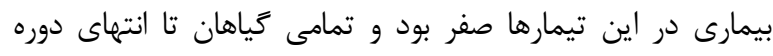
كشت شادابى و طراوت خود را حفظ كردند (شكل بأ). 
(شكل 9). بيشترين محتواى فنل كل در تيمارهاى قارج و باكترى

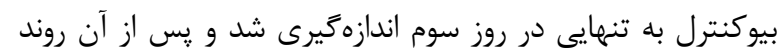

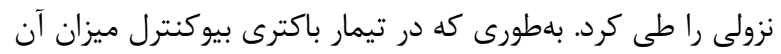

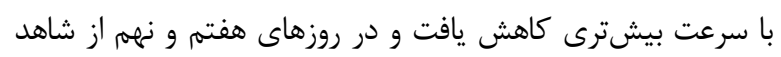

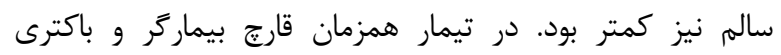

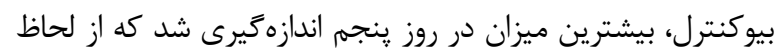

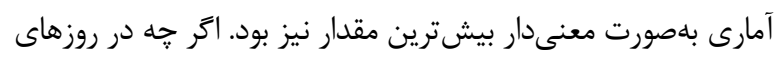

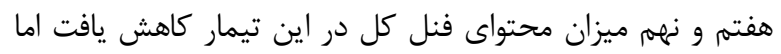

$$
\text { بلهورت معنى دارى بيشتر از ساير تيمارها بود. }
$$

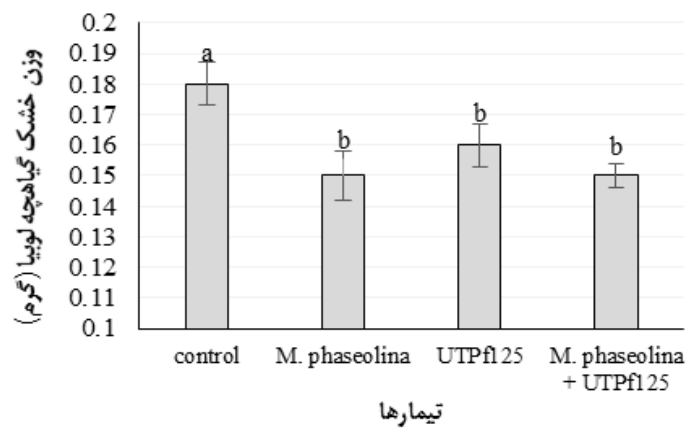

محتواى فنل كل در كياهان تيمار شده با قارج و باكترى

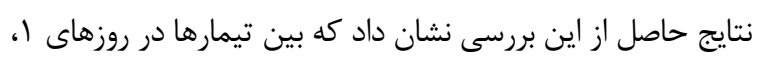

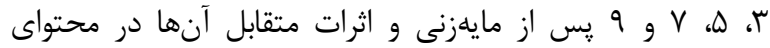

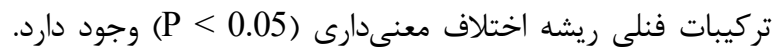

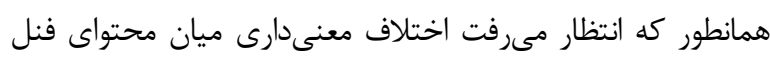

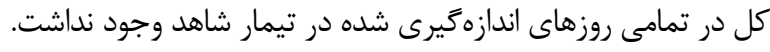

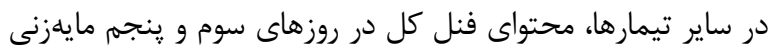

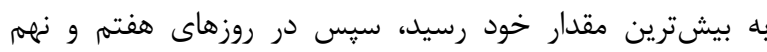

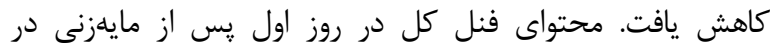

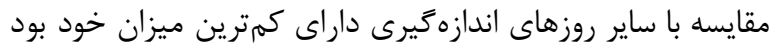

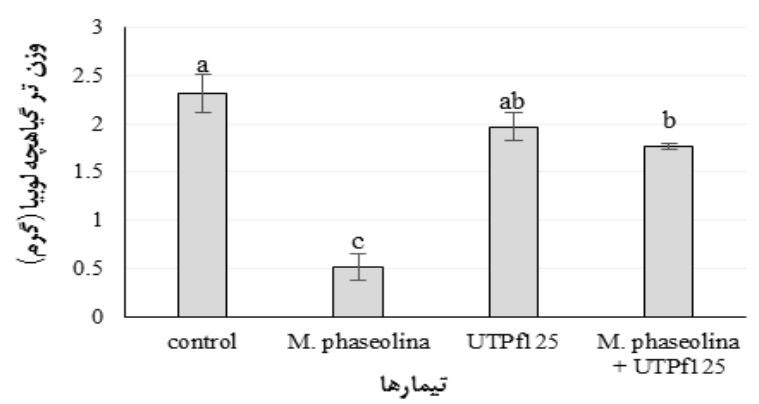

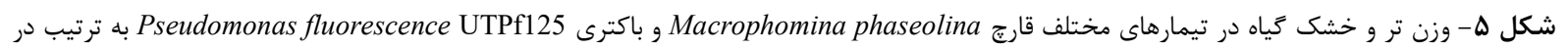

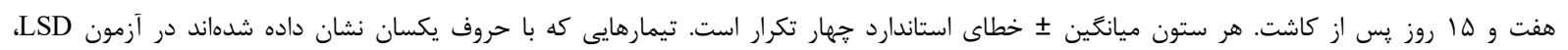

(P<0.01) با يكديكر تفاوت معنى دارى ندارند.

Fig. 5. Fresh and dry weight of the plants in different treatments of Macrophomina phaseolina and Pseudomonas fluorescence UTPf125, 7 and 15 days after sowing, respectively. Data are the means $\pm \mathrm{SE}$ of four replicates. Treatments with the same letters do not differ significantly $(\mathrm{P}<0.01)$ according to LSD test.

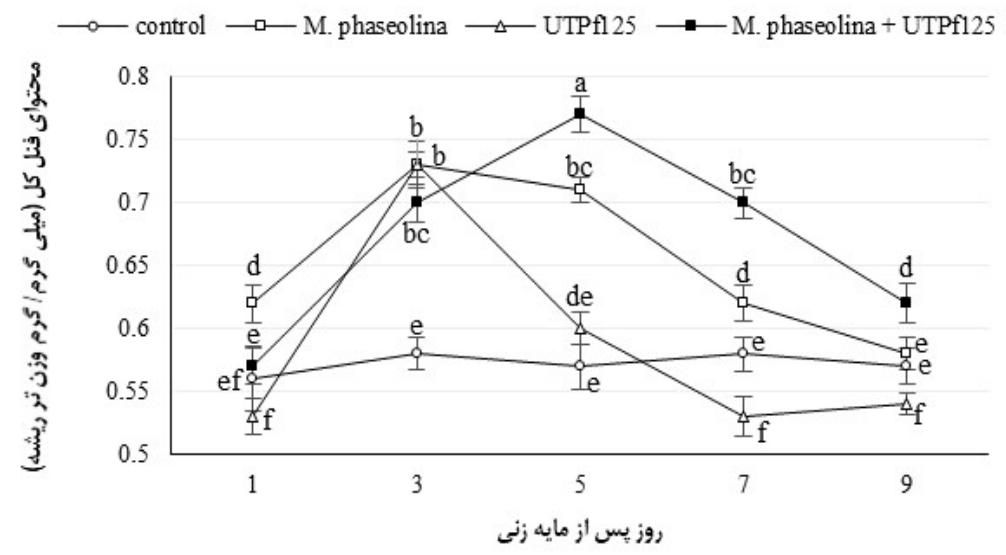

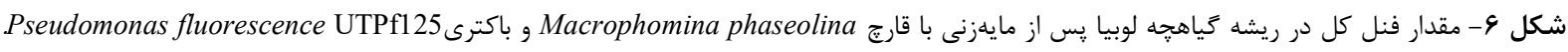

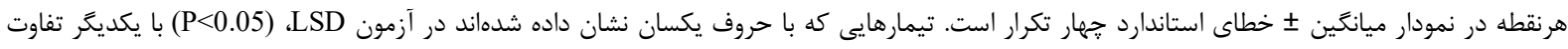
معنى دارى ندارند.

Fig. 6. Total phenol content in bean seedling root after inoculation with Macrophomina phaseolina and Pseudomonas fluorescence UTPf125. Data are the means \pm SE of four replicates. Treatments with the same letters do not differ significantly $(\mathrm{P}<0.05)$ according to LSD test. 
فلورسنت UTPf125 تاثير قابل توجهى در كنترل بيماركر

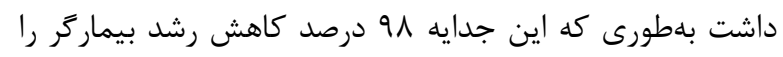

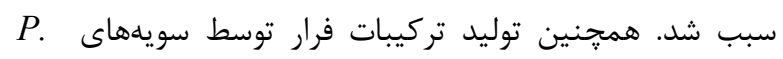

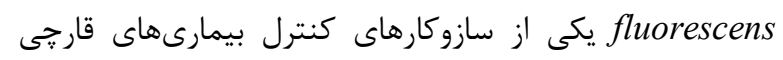
است (Kraus \& Loper, 1992; Laville et al., 1998). نتايج إنى نشان داد كه سويه سودوموناس فلورسنت UTPf125 داراى

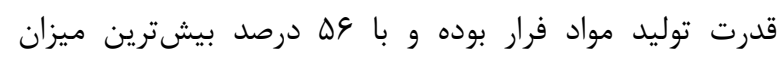

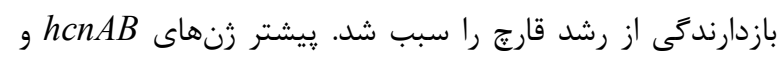
phlD آنتىبيوتيك DAPG هستند در سويه

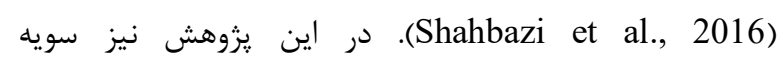
UTPf125

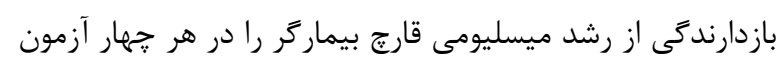

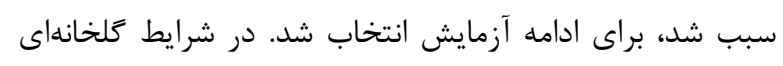

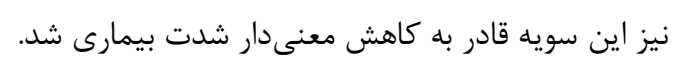

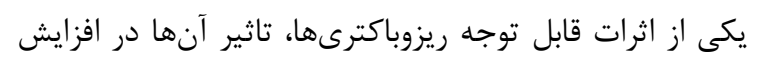

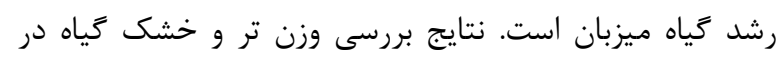
تيمارهاى مختلف نشان داد كه استفاده از باكترى آنتاكونيست

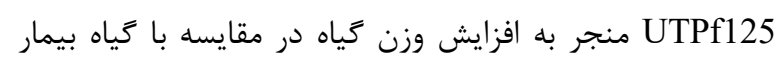

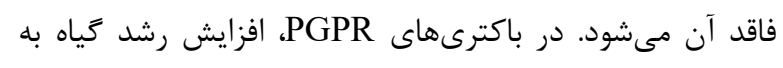

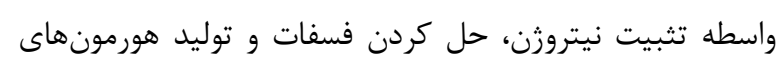

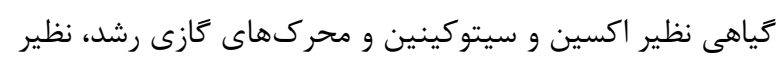

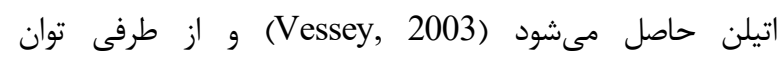

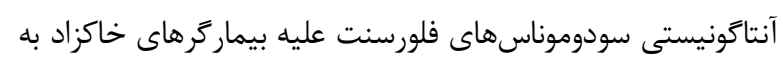

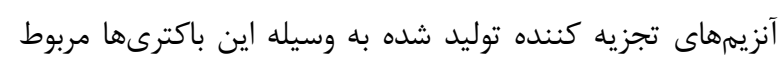

مىشود (Meena et al., 2001; Velazhahan et al., 1999). در مهار زيستى براى انتخاب سويههاى آنتاكونيست بايد

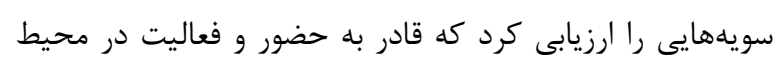

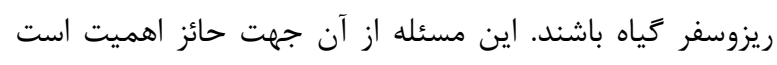

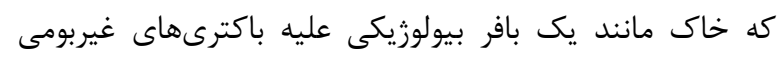

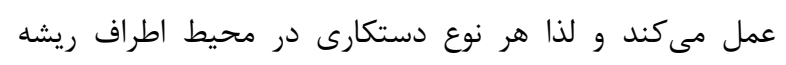

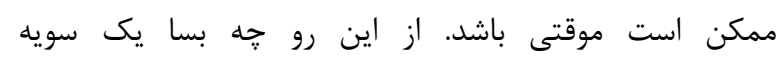

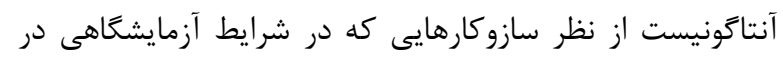

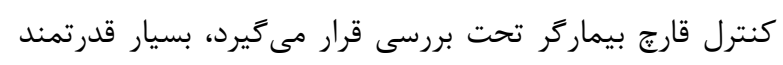

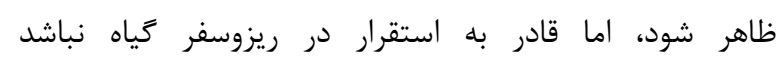
UTPF125 Weller, 1988)

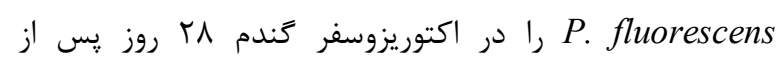

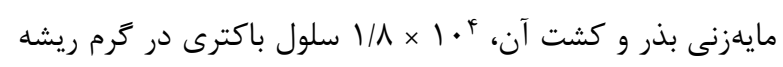

بيان كردند (Shahbazi et al., 2016).
قارج M. phaseolina عامل بيمارى يوسيدگى ذغالى، يكى از

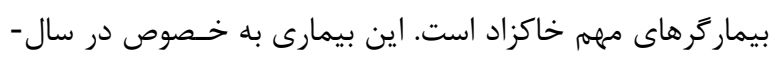

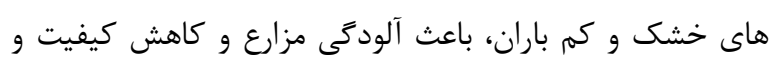
كميت محصول مىشود (Smith \& Wyllie, 1999). دامنه ميزبانى وسيع و توان توليد اسكلروت مقاوم در اين قارج باعث

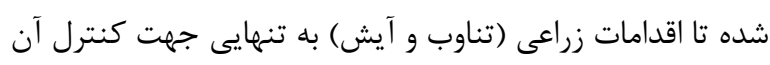

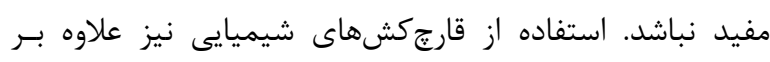

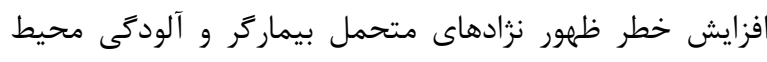
زيست، اثر ناجيزى بر كنترل اين بيمارى داشتهاند ( Siddiqui (\& Mahmood, 1993; Eraghi \& Rahnama, 2010 مهار زيستى مانند باكترىهاى افزايش دهنده رشد گياهى

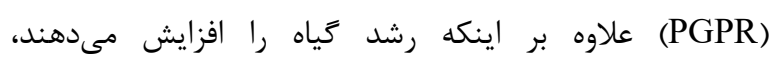
مكانيسمهاى مقاومت سيستميك را نيز در ميزبان فعال مى كنند

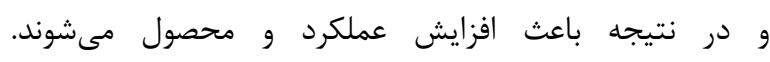
باكترىهاى آنتاگونيست محيط ريشه يكى از

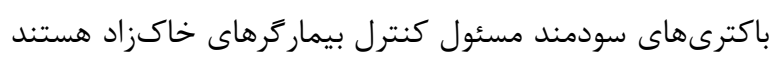

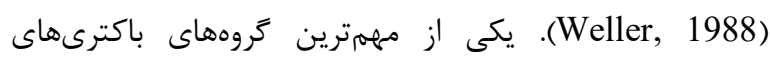
SGPR

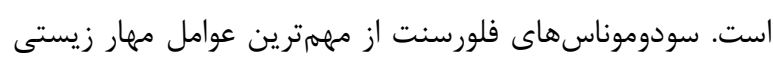
بيمارىهاى كياهى هستند كه به صورت مستقيه، با توليد و و

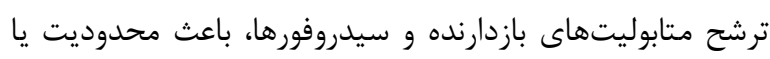

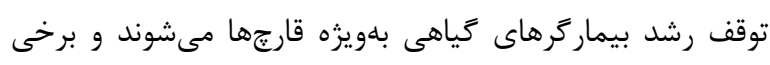

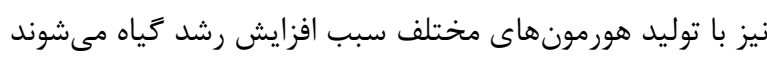
(Ahmadzadeh \& Ghasemi, 2012) آنتىبيوتيكها با تاثير روى بيمارگر و مختل ساختن اعمال

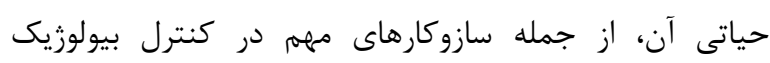
محسوب مىشوند. در اغلب سيستمهاى بيمار گر -ميزبان، سازوكار اوليه مهار زيستى بيماركر توسط سودوموناسها سازوكار آنتىبيوز است (Thomashow \& Weller, 1991). به نظر مىرسد كه به كارايى متغير اين باكترىها ممكن است از تغيير در توليد متابوليتهاى ضدميكروبى در شرايط مختلف محيطى ناشى شود.

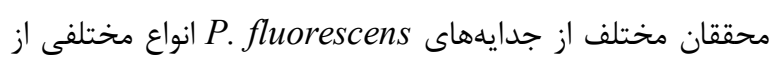

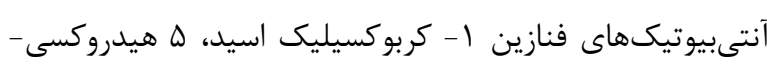

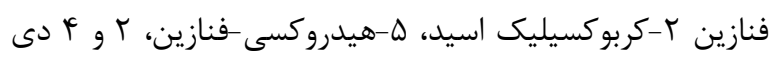

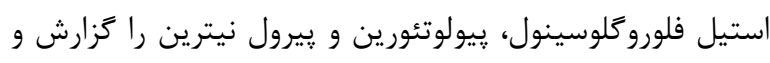
تاثيرات آنها در بازدارى از رشد ريسه قارجها، باكترىهاى ترم

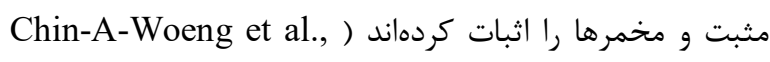
كه دان كه در آزمون توليد متابوليتهاى غير فرار، سويه سودوموناس 
روزهاى بعدى نيز بلصورت معنىدارى بيشتر از شاهد سالم و

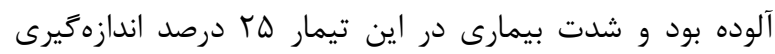

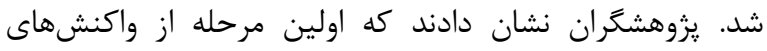
دفاعى گياه ميزبان شامل تجمع سريع تركيبات فنلى در محل

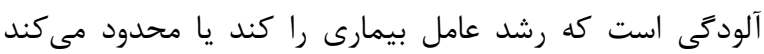
(Matern \& Kneusel, 1988) بيشتر تركيبات فنلى در ريشه گياهان گندم آلوده به قارج عامل به

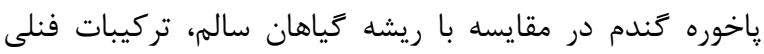
موجود در ريشه را در ميزان حساسيت ارقام گَندم به قارج دخيل

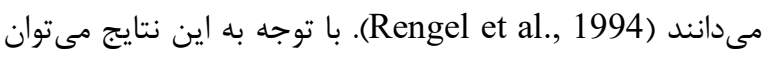

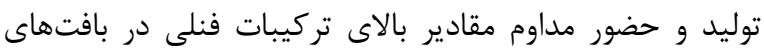

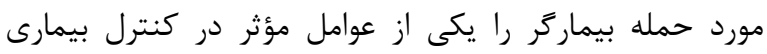

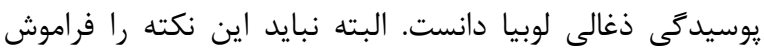
كرد كه در يك رابطه مهار زيستى، مجموعهاى از سازوكارهاى دئي

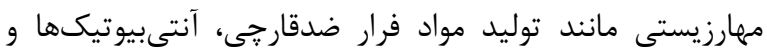
رقابت در كنار القاى مقاومت گياه دخيل هستند كه به افزايش وزن تر و خشك و كاهش •له درصدى شدت بيمارى در كياهان آلوده در اين يزوهش منجر شدند.

$$
\text { سياسخزارى }
$$

از همفكرى و مشاوره دكتر دهقان، مركز تحقيقات كشاورزى و

$$
\text { منابع طبيعى استان لرستان قدردانى مىنماييه. }
$$

\section{REFERENCES}

Ahmadzadeh, M. \& Ghasemi, S. 2012. Introduction of Pseudomonas fluorescens as a new biocontrol agent in Iran. BCPPD 1: 49-60.

Ammarlou, A., Rouhani, M. \& MehdikhaniMoghaddam, A. 2010. Identification and investigation of pathogenicity of fungi causing root rot of wheat in North Khorasan province. JPP 24: 269-284.

Behrouzin, M. 1997. Effect of Puccinia striformis on some physiological, biochemical and histological phenomena of two wheat cultivars. Ph.D. dissertation in Plant Pathology. Tarbiat Modarres University. Tehran. 199 p.

Bhatia, I., Uppal, D. \& Bajaj, K. 1972. Study of phenolic contents of resistant and susceptible varieties of tomato (Lycopersicum esculentum) in relation to early blight disease. Indian Phytopath. 25: 231-235.

Brisbane, P.G., Janik, L.J., Tate, M. \& Warren, R. 1987. Revised structure for the phenazine antibiotic from Pseudomonas fluorescens 2-79 (NRRL B-15132). Antimicrob. Agents Chemother. 31: 1967-1971.

Madloo, P. B., Behboudi, K., Tohidfar, M., Jouzani, G. S. \& Ahmadzadeh, M. 2013. Response of some important Iranian wheat cultivars to Fusarium culmorum under genetic diversity of indigenous biocontrol agent fluorescent Pseudomonas spp. Austral. J. Crop Sci. 7: 1003-1009.
يكى از جنبههاى مهرم دفاعى گياه ميزبان در برابر عوامل

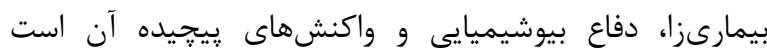

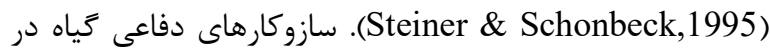
يك زمان بسيار كوتاه در رياسخ به تنشهاى زنده و غيرزنده فعال

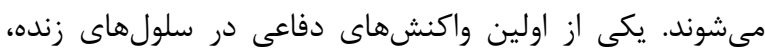

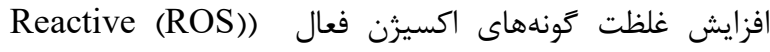
ROS است به طور طبيعى در غلظت (Oxygen Species كم در سلولهاى زنده وجود دارند و در شرايط تنش ميزان آنها

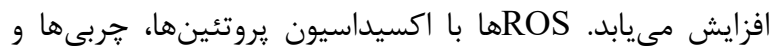
اسيدهاى نوكلئيك و تجزيه مولكولهاى ضرورى سلول سبب اختلال در عملكرد آنها مىشوند. توليد و انتشار سلول گياه اثر سمى مستقيم بر روى سلولهاى بيماركر دارد و و مىتواند منجر به مرى بيماركر شود (Kulbat, 2016). تياهان به منظور محافظت از بافتهاى خود، سيستم آنتى اكسيدانى

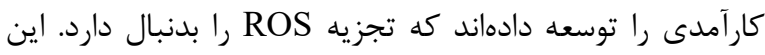

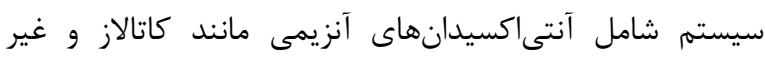

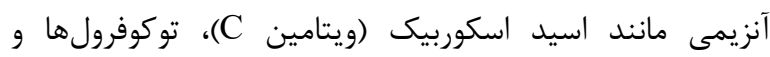

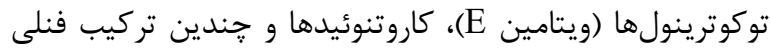

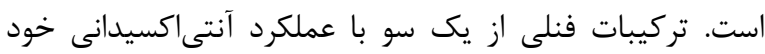

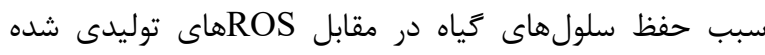
(Gill \& Tuteja, 2010; Sharma et al., 2012) ديگر بهعنوان يِيش ساز بيوسنتز ليخنين عمل كرده و نقش

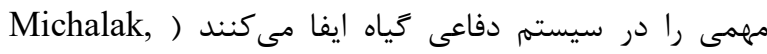

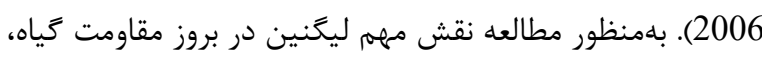

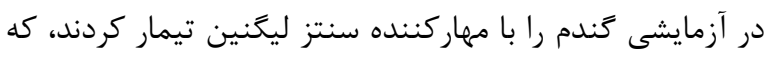

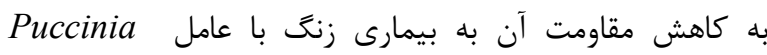

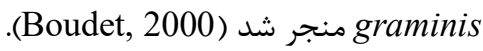
ميزان تركيبات بيوشيميايى توليد شده ازجمله تركيبات فنلى سلى

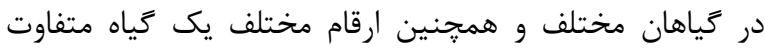

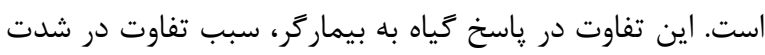
بيمارى ايجاد شده مىشود (Shahbazi et al., 2010). در اين

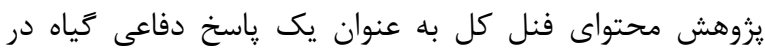

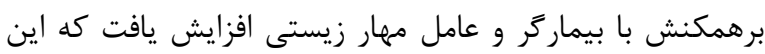
نتايج با نتايج Behrouzin (1997) مطابقت داشت. در ديمار تيمار

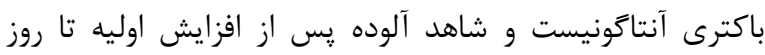

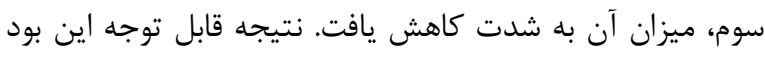

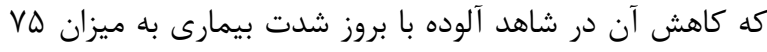

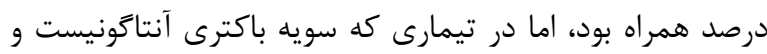

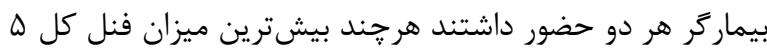
روز يس از مايهزنى اندازهخيرى شد و سيس كاهش يافت، اما در 
Chancey, S.T., Wood, D.W., Pierson, E.A. \& Pierson, L.S. 2002. Survival of GacS/GacA mutants of the biological control bacterium Pseudomonas aureofaciens 30-84 in the wheat rhizosphere. Appl. Environ. Microbiol. 68: 3308-3314.

Chehri, k., Abbasi, S., Reddy, K. \& Salleh, B. 2010. Occurrence and pathogenicity of various pathogenic fungi on cucurbits from Kermanshah province, Iran. African J. Microbiol. Res. 4: 1215-1223.

Chin-A-Woeng TF, de Priester W, van der Bij AJ, \& Lugtenberg, BJ. 1997. Description of the colonization of a gnotobiotic tomato rhizosphere by Pseudomonas fluorescens biocontrol strain WCS365, using scanning electron microscopy. MPMI 10: 7986.

Dadgar, M. 2009. Flourishing in Lorestan agriculture. Jihad-e-Agriculture Organization of Lorestan Province Press, $174 \mathrm{pp}$.

Dennis, C. \& Webster, J. 1971. Antagonistic properties of specific groups of Trichoderma: production of nonvolatile antibiotics. Trans. Br. Mycol. Soc. 57: 25-39.

Dhingra, O.D. \& Sinclair, J.B. 1973. Location of Macrophomina phaseoli on soybean plants related to culture characteristics and virulence. Phytopathol. 63: 934-936.

Dhingra, O.D., \& Sinclair, J. B. 1995. Basic plant pathology methods. Boca Raton: Lewis publishers, $434 \mathrm{pp}$.

Eraghi, M.M. \& Rahnama, K. 2010. Evaluation of Bacillus subtilis isolates in biological control of sunflower root rot caused by Macrophomina phaseolina (Tassi) Goid. JPP 34: 1-11.

Ershad, D. \& Shirazi, G.H. 2004. Melon charcoal disease. JPP 5: 1-7.

Etebarian, H.R., Kheiri, A., Roustaei, A., Khodakaramian, G.H. \& Aminian, H. 2007. Evaluation of Pseudomonas isolates for biological control of charcoal stem rot of melon caused by Macrophomina phaseolina. Acta Hort. 761: 157-162.

Etebarian, H.R., Sholberg, P.L., Eastwell, K.C. \& Sayler, R.J. 2005. Biological control of apple blue mold with Pseudomonas fluorescens. Can. J. Microbiol. 51: 591-598.

Expert, J. \& Digat, B. 1995. Biocontrol of Sclerotinia wilt of sunflower by Pseudomonas fluorescens and Pseudomonas putida strains. Can. J. Microbiol. 41: 685-691.

Fiddaman, P. \& Rossall, S. 1993. The production of antifungal volatiles by Bacillus subtilis. J. Appl. Bacteriol. 74: 119-126.

Gill, S. S. \& Tuteja, N. 2010. Reactive oxygen species and antioxidant machinery in abiotic stress tolerance in crop plants. Plant physiol. and biochem. 48: 909930

Golpaygani, S., Zafari, D. \& Khodakaramian, G. 2011. Biological control of important factors of root rot of bean by extra-root antagonist bacteria. Iranian J. Plant. Prot. Sci. 41: 283-292.

Howell, C. \& Stipanovic, R. 1980. Suppression of Pythium ultimium induced damping off of cotton seedlings by Pseudomonas fluorescens and its antibiotic pyoluteorin. Phytopathol. 70: 712-715.

Jain, A.K. \& Yadav, H.S. 2003. Biochemical constituents of finger millet genotype associated with resistant to blast caused by Pyricularia grisea. Annu. Plant Protect. Sci. 11: 70-74.

Jimenez-Diaz, R.M., Blanco-López, M.A. \& Sackston, W.E. 1983. Incidence and distribution of charcoal rot of sunflower caused by Macrophomina phaseolina in Spain. Plant Dis. 67: 1033-1036.

Keel, C., Schnider, U., Maurhofer, M., Voisard, C., Laville, J., Burger, U., Wirthner, P., Haas, D. \& Dfago, G. 1992. Suppression of root diseases by Pseudomonas fluorescens CHA0: importance of the bacterial secondary metabolite 2, 4diacetylphloroglucinol. MPMI 5: 413.

Keel, C. \& Defago, G. 1997. Interaction between Beneficial Soil Bacteria and Root pathogen: Mechanism and Ecological impact. Black well scientific publishers, London, pp: 27-46.

Kliebenstein, D.J. 2004. Secondary metabolites and plant/environment interactions: a view through Arabidopsis thaliana tinged glasses. Plant Cell Environ. 27: 675-684.

Kraus, J. \& Loper, J. 1992. Lack of evidence for a role of antifungal metabolite production by Pseudomonas fluorescens Pf-5 in biological control of Pythium damping off of cucumber. Phytopathol. 82: 264-271.

Kulbat, K. 2016. The role of phenolic compounds in plant resistance. Biotechnol. Food Sci. 80: 97-108.

Laville, J., Blumer, C., Von Schroetter, C., Gaia, V., Défago, G., Keel, C. \& Haas, D. 1998. Characterization of the honABC gene cluster encoding hydrogen cyanide synthase and anaerobic regulation by ANR in the strictly aerobic biocontrol agent Pseudomonas fluorescens CHA0. J. Bacteriol. 180: 3187-3196.

Leong, J. 1986. Sidrophores: their biochemistry and possible role in the biocontrol of plant pathogens. Annu. Rev. phtopathol. 24: 187-209.

Majnoun Hosseini, N. 2008. Agronomy and beans production. University of Tehran Press, 294 pp.

Matern, U. \& Kneusel, R. 1988. Phenolic compounds in plant disease resistance. Phytoparasitica 16: 153-170.

Mazzola, M., Cook, R.J., Thomashow, L.S., Weller, D. \& Pierson, L. 1992. Contribution of phenazine antibiotic biosynthesis to the ecological competence of fluorescent pseudomonads in soil habitats. Appl. Environ. Microbiol. 58: 2616-2624.

Meena, B., Marimuthu, T., Vidhyasekaran, P. \& Velazhahan, R. 2001. Biological control of root rot of groundnut with antagonistic Pseudomonas fluorescens strains. J. Plant. Dis. Prot. 108: 369-381.

Michalak, A. 2006. Phenolic compounds and their antioxidant activity in plants growing under heavy metal stress. Pol. J. Environ. Stud. 15: 523-530.

Ministry of Agriculture Statistics. 2017. Agricultural Statistics Crop Season 1391-92. In Economic and planning department. Center for Information and Communication Technology. Ministry of Agriculture Jihad Press, 154 pp. 
Obethasli, T., Defago, G. \& Haas, D. 1991. Indole-3acetic acid (IAA) synthesis in the biocontrol strain $\mathrm{CHAO}$ of Pseudomonas fluorescences: role of tryptophan side chain oxidase. J. Gen. Microbiol. 137: 2273-2279.

Pahlavani, M.H., Razavi, S.E., Mirizadeh, I. \& Vakili, S. 2006. Field screening of safflower genotypes for resistance to charcoal rot disease. Int. J. Plant Prod. 1: 45-52.

Parashar, A. \& Lodha, P. 2007. Phenolics estimation in Foeniculum vulgare infected with Ramularia blight. Annu. Plant Protect. Sci. 15: 396-398.

Purkayastha, S., Kaur, B., Dilbaghi, N. \& Chaudthury, A. 2006. Characterization of Macrophomina phaseolina, the charcoal rot of cluster bean, using conventional techniques and PCR based molecular markers. Plant Pathol. 55: 106-116.

Rengel, Z., Pedler, J.F. \& Graham, R.D. 1994. Control of $\mathrm{Mn}$ status in plants and rhizosphere: genetic aspects of host and pathogen effects in the wheat takeall interaction. In Manthey, J.A., Crowley, D.E. \& Luster, D.G. (eds.), Biochemistry of Metal Micronutrients in the Rhizosphere. 125-145. CRC Press, Boca Raton, FL, USA.

Savchuk S, Fernando WGD, Parks PS. 2001. Potential for biocontrol of Sclerotinia sclerotiorum on canola. Can. J. Plant Pathol. 23: 205.

Schippers, B., Bkker, A.W. \& Bakker, P. 1987. Interaction of deleterious and beneficial rhizospher microorganism and the effect of cropping practices. Annu. Rev. Phytopathol. 25: 339-358.

Seevers, P.M. and Daly, J.M. 1970. Studies on wheat stem rust resistance controlled at the sr 6 locus 1- the role of phenolic compounds. Phytopathol. 60: 13221328.

Shahbazi, H., Aminian, H., Sahebani, N. \& Halterman, D.A. 2010. Biochemical evaluation of resistance responses of potato to different isolates of Alternaria solani. Phytopathol. 100: 454-459.

Shahbazi, H., Behboudi, K, Javan Nikkhah, M. \& Ahmadzadeh, M. 2016. Detection of hcnAB and phlD genes in fluorescent pseudomonads biological control agent of Fusarium graminearum and studying their ability to ectorhizosphere colonization of wheat. Biol. Control Pests Plant Dis. 4: 143-155.
Shanahan, P., O'Sullivan, D.J., Simpson, P., Glennon, J.D. \& O'Gara, F. 1992. Isolation of 2,4 diacetylphloroglucinol from a fluorescent pseudomonad and investigation of physiological parameters influencing its production. Appl. Environ. Microbiol. 58: 353-358.

Sharma, P., Jha, A. B., Dubey, R. S. \& Pessarakli, M. 2012. Reactive oxygen species, oxidative damage, and antioxidative defense mechanism in plants under stressful conditions. J. Botany 217037: 1-26.

Siddiqui, Z. A. \& Mahmood, I. 1993. Biological control of Meloidogyne incognita race 3 and Macrophomina phaseolina by Paecilomyces lilacinus and Bacillus subtilis alone and in combination in chickpea. Fund. Appl. Nematol. 16: 215-218.

Smith, G.S. \& Wyllie, T.D. 1999. Charcoal Rot. In Hartman, G.L., Sinclair, J.B. \& Rupe, J.C. (eds.), Compendium of soybean disease. 29-31. APS Press, American Phytopathological Society.

Steiner, U. \& Schönbeck, F. 1995. Induced resistance to disease in plants. In Hammerschmialt, R. \& Riyc, J. (eds.), Development in plant pathology. 86-110. Kluwer Academic Publishers.

Thomashow, L.S. \& Weller, D.M. 1991. Role of antibiotics and sidrophores in biocontrol of take-all disease of wheat. Springer, Dordrecht, 245-251 pp.

Velazhahan, R., Datta, S.K. \& Muthukrishnan, S. 1999. The PR-5 family: Thaumatin-like proteins. In Datta S.K., \& Muthukrishnan, S. (eds.), Pathogenesisrelated proteins in plants. CRC Press, pp: 107-129.

Vessey, K.J. 2003. Plant growth- promoting rhizobacteria as biofertilizers. Plant Soil 255: 571580 .

Voisard, C.H., Keel, C.H., Haas, D. \& Defago, G. 1989. Cyanide production by Pseudomonas fluorescence helps suppress black root rot of tobacco under gootobiotic condition. EMBO J. 351-358.

Weller, D. 1988. Biological control of soilborne plant pathogens in the rhizospher with bacteria. Annu. Rev. phytopathol. 26: 379-407.

Yamamoto, H., Hokin, H., Tani, T. \& Kadota, G. 1977. Phenylalanine ammonia-lyase in relation to the crown rust resistance of oat leaves. J. Phytopathol. 90: 203-211.

How to cite this article:

Pas, M., Shahbazi, H. \& Ebrahimi, L. 2020. The biocontrol potential of Pseudomonas fluorescens against Macrophomina phaseolina and estimating the total phenol compounds of bean roots in this interaction. Nova Biologica Reperta 7: 64-75. (In Persian).

$$
\begin{aligned}
& \text { ياس، م.، شهبازى، ح. و ابر اهيمى، ل. وجس ا. بررسى اثر مهار زيستى قارج Macrophomina phaseolina توسط باكترى سودوموناس فلورسنت روى گياه }
\end{aligned}
$$

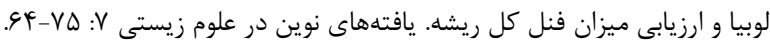

